\title{
Membumikan Karya Inovatif Fenomenal Dan Spektakuler Peserta Didik Berbakat di Bidang MIPA Untuk Indonesia yang Maju dan Kompetitif di Era Globalisasi
}

\author{
${ }^{1}$ Abdul Hadis, ${ }^{1}$ Usman dan ${ }^{1}$ St. Kasmawati \\ Jurusan Fisika FMIPA UNM
}

Email: abdulhadis70@yahoo.com

\begin{abstract}
Abstrak - Era globalisasi sarat dengan kompetisi dalam berbagai aspek kehidupan. Bangsa yang unggul dalam berkompetisi menguasai IPTEKS, khususnya Teknologi Komunikasi dan Informasi dewasa ini, maka akan menguasai dunia. Untuk menguasai TIK harus kuat basisnya dalam bidang MIPA sebagai ilmu dasar dalam menguasai IPTEKS. Salah satu sumberdaya manusia yang menjadi tumpuan setiap bangsa sebagai ujung tombak terdepan dalam penguasaan IPTEKS secara cepat dan tepat ialah peserta didik yang berbakat intelektual, seperti yang telah dibuktikan oleh negara maju seperti Jerman, Jepang, Amerika Serikat, Perancis, dan negara maju lainnya.
\end{abstract}

Kata kunci: karya inovatif fenomenal, spektakuler, peserta didik berbakat, maju dan kompetitif, globalisasi.

\begin{abstract}
Abstrack - The era of globalization is full of competition in various aspects of life. Nations who excel in competing in Science and technology, especially Information and Communication Technology, it will rule the world. To master ICT must strong base in the field of Mathematics as a basic science in mastering science and technology. One of the human resources that became the foundation of every nation as the leading spearhead in the mastery of science and technology quickly and accurately is intellectually gifted learners, as has been proven by developed countries such as Germany, Japan, the United States, France and other developed countries.
\end{abstract}

Keywords: innovative works of phenomenal, spectacular, gifted learners, advanced and competitive, globalization.

\section{PENDAHULUAN}

Tidak dapat disangkal dan tidak dapat dibantah, bahwa kemajuan suatu negara sangat ditentukan oleh kualitas sumberdaya manusianya. Sudah banyak negara kecil di dunia ini yang memiliki kualitas dan kuantitas sumberdaya manusia yang sedikit dan rendah, namun karena memiliki kualitas sumberdaya manusia yang handal, maka negara tersebut berstatus negara maju yang memiliki daya saing yang tinggi, bahkan berkelas dunia. Sebagai contoh, Singapura adalah negara kecil di Asia, jika dilihat dari perspektif luas wilayahnya secara geografis dan jumlah penduduknya, namun kualitas sumberdaya manusianya berkelas dunia. Hal ini dibuktikan oleh fakta, yaitu Singapura sampai sekarang ini masih dijuluki sebagai "Macannya Asia".

Pemberian julukan "Macan Asia" kepada negara Singapura sangat beralasan, karena Singapura termasuk negara yang memiliki mutu pendidikan

dan sistem pendidikan yang baik atau bermutu, yang selevel dengan mutu

pendidikan negara Hongkong dan Jepang. Selain itu, hasil survei World Economic menyimpulkan dan membuktikan bahwa indeks daya saing negara Singapura di tahun 2014 ialah berada di peringkat kedua dunia.

Sebaliknya, Indonesia sebagai negara terbesar dan terluas di Asia secara geografis yang memiliki sekitar $17.000,-$ pulau atau bahkan lebih dengan jumlah penduduk yang sxangat besar, yaitu 255.993.674,- di tahun 2016 (Bank Dunia, 2016).Menurut Bank Dunia tersebut, juga dilaporkan bahwa kualitas

sumberdaya manusia Indonesa, juga menunjukkan kualitas sumberdaya manusia yang rendah. Fakta ini dapat dilihat dari segi profil tingkat pendidikan penduduk Indonesia berdasarkan hasil survei di tahun 2010, yaitu penduduk yang bependidikan SD sebesar 51,5 $\%$, SMP $=18,9 \%$, SMA $=14,6 \%$, SMK $=$ $7,8 \%$, diploma 1,2 , dan $3=2,7 \%$, S1 ke atas $=4,6 \%$ dan yang berpendidikan professor atau guru besar baru 0,002 \% dari jumlah populasi penduduk Indonesia, sedangkan di Singapura, rata-rata penduduknya telah berpendidikan tinggi, apalagi Jepang sebagai salah satu negara maju di Asia telah memiliki jumlah doktor yang banyak dengan perbandingan 6. 438 doktor per satu juta 
penduduk, sebaliknya di Indonesia terdapat 120 doktor setiap populasi penduduk berjumlah satu juta penduduk (Hasil penelitian Webometrics di tahun 2010).

Dengan kondisi profil tingkat pendidikan penduduk Indonesia tersebut di atas, diduga menjadi faktor penyebab indeks daya saing Indonesia di tingkat internasional atau di tingkat dunia, yaitu posisi ke 34, menurut hasil penelitian "World Economic". Fakta tersebut di atas, harus menjadi bahan pelajaran dan harus membuat kita sebagai bangsa yang besar, yaitu Bangsa Indonesia malu di mata dunia atas kenyataan pahit ini. Oleh karena itu, salah satu resep yang ampuh untuk meningkatkan harkat dan derajat Bangsa Indonesia dilihat dari segi indeks daya saingnya ialah "Menanamkan dan menerapkan disiplin tinggi" kepada semua penduduk Indonesia yang berbasis "Wal Ashri" secara murni dan konsekuen dalam belajar dan bekerja dengan etos kerja dan belajar yang sangat tinggi apapun profesi kita”.

Selain itu, prinsip peningkatan produktivitas berbasis "Faiza faragta fanzab waila rabbika faragab" yang berbasis pada $\mathrm{Al}$ Qur'an surah Al Insyiro" harus ditanamkan dan diamalkan oleh setiap penduduk Indonesia."Faiza faragta fanzab waila rabbika faragab" mengandung makna yang sangat dalam dan sangat luar biasa, yaitu "Jika kamu telah selesai mengerjakan satu pekerjaaan dengan tuntas dan bermutu, maka pindah lagi mengerjakan pekerjaan yang lain". Makna yang dikandung dari pernyataan yang tersurat dalam surah Al Insyiro di dalam Al Qur'anul Karim adalah "Makna Produktivitas" yang sangat luar biasa. Roda perekonomian Indonesia akan berputar terus jika prinsip produktivitas dalam surah $\mathrm{Al}$ Insyiro tersebut diterapkan secara konsisten dan konsekuen.

Selain data tentang profil kualitas pendidikan dan kualitas sumberdaya manusia yang ada di negara maju seperi Singapura dan Jepang, profil tingkat kreativitas siswa, mahasiswa, dan penduduk Singapura dan Jepang lebih tinggi daripada Indonesia. Hal dibuktikan oleh karya atau produk teknologi dari Jepang lebih banyak daripda produk teknologi dari Indonesia, seperti produk teknologi berupa mobil, sepeda motor, alat-alat pertanian, dan produk teknologi jenis lainnya.

Tingginya tingkat kuantitas dan kualitas produk teknologi dari Jepang, tidak terlepas dari kontribusi besar dari para sumberdaya manusia Jepang yang berbakat intelektual, berbakat teknologi dan melek IPTEKS. Oleh karena itu,

upaya identifikasi sumberdaya manusia yang berbakat, baik yang berkategori jenius, talented, dan gifted di Indonesia mutlak dilakukan agar menjadi pelaku-

pelaku pembangunan yang handal dan kompetitif yang berkelas dunia. Dari kontrbusi populasi sumberdaya manusia yang berbakat tersebut, yang didukung oleh seluruh populasi penduduk dan didukung oleh pemerintah yang handal dalam memimpin dengan membuat regulasi dan kebijakan yang memberikan kesempatan seluas-luasnya kepada manusia berbakat di Indonesia untuk mengembangkan bakatnya secara maksimal dan optimal, maka Insya Allahdapat dipastikan bahwa Indonesia akan menjadi negara maju juga yang bersaing kelas dunia yang akan disegani oleh negara lain. Untuk itu, sangat urgen dilakukan penelitian tentang "Identifikasi Peserta Didik Berbakat Di Madrasah Tsanawiah (MTs) Model Makassar Berdasarkan Ciri-ciri Belajar, Kreativitas, Kepemimpinan, dan Motivasi dalam skala kecil sesuai dengan biaya penelitian yang tersedia.

\section{Pembahasan}

\section{Pengertian Peserta Didik Yang Berbakat}

Anak berbakat atau peserta didik berbakat (istilah yang digunakan oleh peneliti) ialah mereka yang memiliki kemampuan intelektual yang unggul (Munandar, 1965). Dengan keunggulan ini, mereka diharapkan memiliki peliuang besar untuk mencapai prestasi tinggi dan menonjol dalam bidang pekerjaan atau profesi yang ditekuni. Anak berbakat juga dapat didefinisikan sebagai anak yang memiliki kemampuan yang unggul di bidang intelektual, seni, olah raga, dan keterampilan tertentu (Kitano dan Kirby, 1989). Peserta didik yang memiliki kemampuan intelektual yang unggul, sering dijuluki sebagai anak yang jenius, sedangkan peserta didik atau anak yang memiliki keunggulan pada satu keterampilan tertentu, misalnya

terampil dalam bermain sepak bola, disebut sebagai anak yang talented dan anak yang memiliki kemampuan yang unggul pada beberapa keterampilan, misalnya memiliki kemampuan unggul dalam memainkan drum (keterampilan di bidang seni) dan bermain sepak bola (keterampilan di bidang olah raga), maka anak seperti ini disebut sebagai anak yang "gifted".

Jadi dapat disimpulkan bahwa peserta didik yang berbakat yang ada di sekolahsekolah (termasuk yang ada di Madrasah Tsanawiyah Model Kota Makassar), dan yang ada di masyarakat, memiliki tiga kategorisasi, yaitu kategori anak yang jenius, kategori anak yang talented, dan kategori anak yang gifted. Namun demikian, ketiga kategori tersebut semuanya bermuara kepada 
istilah anak yang berbakat atau peserta didik yang berbakat yang menunjuk

kepada sekelompok individu yang memiliki kelebihan yang luar biasa, baik di bidang intelektual, seni, olah raga, dan berbagai bidang kehidupan lainnya, yang membedakan dengan anak yang biasa atau anak normal pada umumnya. Individu atau kelompok individu yang masuk kategori anak yang berbakat memiliki kontribusi yang sangat luar biasa bagi masyarakat, baik masyarakat lokal, regional, nasional, dan bahkan masyarakat dunia. Berbagai contoh nyata orang berbakat yang telah tekenal seantero dunia karena temuannya di bidang IPTEKS yang memudahkan kehidupan ummat manusia di dunia ini, misalnya Thomas Edison penemu listrik dan Elbert Einstein sebagai tokoh ilmu pengetahuan, dan berbagai ilmuan berkelas dunia lainnya.

\section{Karakteristik atau Ciri Khas Peserta Didik Berbakat}

Peserta berbakat memiliki beberapa ciri khas atau karakteristik yang ditunjukkan oleh perilaku mereka dalam kehidupannya sehari-hari. Menurut Kitano dan Kirby (1989), terdapat banyak karakteristik yang dapat ditunjukkan oleh mereka yang tergolong anak berbakat, yaitu diantaranya: memiliki perbendaharaan kata yang sangat banyak atau sangat luas, menaruh minat yang besar terhadap buku-buku dan berusaha untuk membacanya sejak usia

dini, mampu membaca sendiri sejak usia awal, yaitu ketika mereka berusia 2-3 tahun, mampu membaca secara independen atau mandiri, mampu mempersepsi hubungan kausal dengan cepat, dorongan ingin tahunya (curiousity) sangat besar, belajar dengan cepat, dan dapat mengungkap kembali

informasi atau segala hal yang telah dipelajari dengan cepat, bekerja keras untuk aktualisasi diri, senang bergaul dengan orang dewasa, dan mampu bertahan lama dalam konsentrasi dalam mengerjakan sesuatu (termasuk ketika mereka belajar.

Selain karakteristik tersebut di atas, anak berbakatjuga menunjukkan karakteristik yang dapat diamati dari perilakunya sehari, baik di lingkungan keluarga, sekolah, dan masyarakat, yaitu memiliki standar diri yang tinggi, menyukai pengalaman baru yang menantang, awet menyimpan informasi, cakap dalam menyusun rencana (baik rencana belajar maupun rencana kerja), mampu memecahkan masalah, mampu berp;ikir abstrak, cepat mengambil generalisasi, cepat mengambil keputusan, cepat melihat perbedaan dan persamaan sesuatu hal atau sesuatu objek, mudak bosan terhadap tugas rutin atau tugas- tugas dan pekerjaan yang monoton, menaruh minat yang dalam terhadap isu-isu etika, agama, dan politik, dan perbendaharaan informasinya banyak dan bervariasi. Sedangkan menurut Marland (1986) mengemukakan bahwa karakteristik atau ciri khas unggulan anak yang tergolong berbakat ialah sebagai berikut: berinteligensi tinggi, memiliki kecakapan akademik khusus, berpikir kreatif dan produktif, cakap dalam memimpin, cakap dalam bidang seni visual, dan memiliki kecakapan psikomotorik.

Para anak berbakat yang memiliki karakteristik yang menonjol di bidang akademik (termasuk di bidang MIPA), keterampilan, seni, dan kepemimpinan, perlu diberikan pendidikan khusus bagi mereka agar bakat mereka dapat berkembang, maju, dan teraktualisasikan. Hal ini sangat beralasan karena anak berbakat yang ada pada setiap negara menjadi sumberdaya manusia yang handal yang memiliki daya saing yang tinggi dalam memajukan suatu negara melalui peningkatan daya saing berkelas dunia.

\section{Pentingnya Layanan Pendidikan Khusus Untuk Peserta Didiik Berbakat}

Dalam memasuki abad ke-21, negara yang sedang berkembang mengalami kompetisi yang luar biasa dalam berbagai sendi kehidupan manusia (Tofler, 1988). Untuk menjawab tantang tersebut, maka pemnbangunan sumberdaya manusia melalui pendidikan, baik pendidikan informal, pendidikan non formal, dan pendidikan formal di berbagai institusi pendidikan, mulai dari jenjang pendidikan dasar sampai pendidikan tinggi, perlu mendapatkan perhatian dan prioritas khusus dari pemerintah (Joni, 1993). Oleh karena itu, sumberdaya manusia yang tergolong berbakat yang berkemampuan unggul perlu diberikan layanan pendidikan khusus dan layanan pembelajaran khusus, agar mampu mengaktualisasikan bakat dan kreativitasnya (Guilford, 1986) dan mengadakan berbagai inovasi di dalam perkembangan masyarakat demi untuk kepentingan dan kesejehateraan masyarakat (Semiawan, 1993 dan Munandar, 1997).

Sejarah di negara lain membuktikan, potensi-potensi unggul yang dimiliki oleh para anak yang berbakat, dipelihara dan ditumbuhkembangkan serta dipupuk melalui pendidikan khusus agar mereka dapat menjadi pemimpin-pemimpin bangsa di masa depan, dan mengaktualisasikan dirinya dalam melakukan berbagai bidang pembangunan di berbagai bidang atau sektor kehidupan yang sarat dengan muatan penguasaan IPTEKS (Horvath, 1989 dan 
Khatena, 1992). Para orangtua, guru, dan masyarakat tidak dapat membiarkan potensipotensi yang dimiliki oleh anak berbakat tersebut tidak teraktualisasikan, terutama dalam menghadapi berbagai perubahan yang disebabkan oleh berbagai revolusi di bidang IPTEKS yang menuntut potensi unggul sumberdaya manusia anak yang berbakat, diaktualisasikan melalui pendidikan agar mereka dapat memberikan sumbangan tenaga, pikiran, dan jiwa raganya untuk masyarakat (Semiawan, 1995 dan Munandar, 1987). Oleh karena itu, para guru dan orang dewasa memegang peranan vital atau

peranan yang sangat penting dalam membantu perkembangan aktual dan potensi anak yang berbakat (Vygotski, 1978).

Mengabaikan pendidikan khusus untuk mereka yang tergolong anak berbakat, baik di lingkungan keluarga, sekolah, dan masyarakat, akan menyebabkan bakat intelektual, kreativitas, dan kemampuan unggul di bidang keterampilan, tidak dapat teraktualisasikan. Bahkan kondisi sebaliknya dapat terjadi, yaitu anak berbakat dapat mengalami "underachiever" yaitu bakat anak tidak berfungsi secara maksimal dan optimal yang sesuai dengan potensi mereka (Gallagher, 1975). Oleh karena itu, pemberian layanan pendidikan dan pembelajaran yang spesifik untuk mereka yang tergolong peserta didik yang berbakat sangat diperlukan, yang diberikan oleh para guru pembimbing khusus untuk anak berbakat, para psikolog, para sosiolog, masyarakat intelektual, dan dari para pakar pendidikan khusus untuk anak berbakat.

\section{Model Program Pendidikan Untuk Peserta Didik Berbakat}

Dalam upaya untuk memberikan layanan pendidikan dan layanan pembelajaran khusus kepada mereka yang tergolong peserta didik yang

berbakat, maka pengembangan dan penerapan model program pendidikan untuk peserta didik yang berbakat, juga perlu menjadi perhatian dan pertimbangan khusus bagi para guru (khususnya guru pembimbing khusus untuk peserta didik yang berbakat), orangtua, dan masyarakat terdidik, terpelajar, dan terlatih dalam membelajarkan dan mendidik peserta didik yang berbakat, baik di lingkungan rumah, lingkungan sekolah, dan di lingkungan masyarakat. Ada empat model program pendidikan yang masih dapat

diterapkan dalam mendidik dan membelajarkan peserta didik yang berbakat di era globalisasi dewasa ini, yaitu: (1) the autonomous learner model yang mencakup lima dimensi, yaitu dimensi orientasi, pengembangan individual, aktivitas pengayaan, seminar, dan pendalaman;
(2) enrichment model yang terdiri atas the enrichment triad/revolving door model: A schoolwide plan for the development of creative productive and the secondary tried; (3) individualized programming planning model, yakni model ini dirancang untuk mengembangkan pembelajaran efektif sebagai respon terhadap keunikan karakteristik, kekuatan, dan bakat setiap anak yang berbakat, (4) the integrative education model. Model yang keempat ini dikembangkan berdasarkan empat fungsi otak manusia, yaitu fungsi berpikir, indera, emosi, dan fungsi intuitif.

Layanan pendidikan dan pembelajaran khusus yang diberikan kepada peserta didik yang berbakat, disesuaikan dengan model program pendidikan yang dirancang khusus untuk mereka yang tergolong peserta didik yang berbakat. Para peserta didik yang telah terindentifikasi sebagai peserta didik yang berbakat, dilihat dari segi ciri-ciri belajar, ciriciri kreativitas, ciri-ciri kepemimpinan, dan ciri-ciri motivasi, perlu diberikan layanan pendidikan dan pembelajaran khusus kepada peserta didik yang berbakat tersebut, oleh guru dan pihak-pihak yang kompeten dengan memberikan:

(1) Pendidikan yang berdiferensiasi dengan penekanan kepada aktivitas intelektual anak yang berbakat (Ward, 1980),

(2) Kurikulum yang berdiferensiasi yang beranjak pada teori spesialisasi belahan otak (Kitano dan Kirby dalam Semiawan, 1992),

(3) Pendekatan pembelajaran induktif dengan metode inquiry, problem solving, discovery learning, scientific method,

(4) School wide enrichment model, dan

(5) Pengelompokkan kemampuan belajar, dan pemberian berbagai layanan dalam berbagai bidang (Kitano dan Kirby dalam Semiawan, 1995).

5. Layanan Pendidikan dan Pembelajaran Untuk Peserta Didik Berbakat

Layanan pendidikan dan pembelajaran khusus untuk peserta didik yang berbakat, bukan saja perlu diberikan kepada peserta didik atau siswa yang mengikuti pendidikan dan pembelajaran di Madrasah Tsanawiyah Model Kota Makassar, yang telah dikenali sebagai peserta didik yang berbakat, melainkan juga kepada semua peserta didik yang berbakat di sekolah lainnya. Oleh

karena itu, usaha identifikasi atau mengenali peserta didik yang berbakat di sekolah-sekolah lain di berbagai institusi pendidikan, juga perlu dilakukan melalui kegiatan penelitian di sekolah-sekolah tersebut untuk menjaring peserta didik yang berbakat di berbagai sekolah tersebut, baik di sekolah-sekolah negeri 
maupun di sekolah-sekolah swasta.

Secara teoritis, peserta didik yang berbakat dapat dikenali melalui ciri-ciri belajar, ciri-ciri motivasi, ciri-ciri kreativitas, dsn ciriciri kepemimpinan yang ditunjukkan oleh para peserta didik tersebut, ketika mereka berperilaku di kelas dalam mengikuti proses pembelajaran MIPA dan materi pelajaran lainnya. Dari segi ciri-ciri belajar, aspek-aspek yang dapat diungkap dalam mengenali peserta didik yang berbakat di kelas atau di sekolah ialah mencakup aspek-aspek sebagai berikut: (1) kemudahan peserta didik dalam menangkap pelajaran, (2) memiliki ingatan yang baik terhadap materi pelajaran, (3) perbendaharaan kata yang luas, (4) kemampuan penalaran (kemampuan berfikir logis, keritis, dan memahami hubungan sebab akibat yang tajam), (5) daya konsentrasi yang tinggi, penguasaan bahan pelajaran yang luas dan mendalam, (7) kegemaran dan frekuensi membaca dalam sehari sangat tinggi, (8) pengungkapan diri secara sosial yang baik, dan (9) kemampuan pengamatan yang cermat dan tepat.

Dari segi ciri-ciri motivasi, aspek-aspek yang dapat diungkap dalam mengenali peserta didik yang berbakat di kelas atau di sekolah ialah mencakup aspek-aspek sebagai berikut: (1) ketekunan dalam mengerjakan tugastugasbelajar, (2) keuletan dalam menghadapi berbagai kesulitan, (3) bermotivasi intrinsik untuk berprestasi, (4) mendalami IPTEKS di kelas, (5) beretos kerja dan belajar yang tinggi, (6) berminat belajar terhadap berbagai macam pengetahuan dan masalah, (7) kesenangan dan kerajinan belajar, (8) keuletan dalam mengerjakan tugas-tugas rutin, (9) kemampuan mempertahankan pendapat, (10) bekerja dan belajar keras untuk mencapai tujuan dan cita-cita di masa depan.

Dari segi ciri-ciri kreativitas, aspekaspek yang dapat dingkap dalam mengenali siswa yang berbakat di sekolah ialah kemampuan dalam hal sebagai berikut: (1) kemampuan memberikan banyak ide/gagasan dan usul solusi terhadap suatu masalah, (2) berani mengemukakan pendapat, (3) rasa ingin tahunya besar, (4) sering mengajukan pertanyaan yang berbobot, dan bebas dalam menyatakan pendapat, (5) memiliki rasa estetika, (6) menonjol pada salah satu atau lebih bidang seni, (7) konsisten dengan pendapat sendiri yang diyakini benar, (8) memiliki rasa humor, (9) memiliki daya imajinasi, dan (10) memiliki orisinalitas dalam memberikan gagasan, ungkapan, karangan, dan dalam pemecahan masalah.
Dari segi ciri-ciri kreativitas,aspekaspek yang dapat dingkap dalam mengenali siswa yang berbakat di sekolah ialah kemampuan dalam hal sebagai berikut: (1) sering menjadi pemimpin di kelas dan di sekolah, (2) disenangi oleh teman, guru, dan staf sekolah lainnya, (3) memiliki sifat koperatif yang tinggi, (4) memiliki inisiatif, (5) kemampuan mempengaruhi teman-teman dan orang lain, (6) memiliki tanggung jawab yang besar, (7) percaya pada diri sendiri, (8) mudah beradaptasi terhadap berbagai situasi sosial di kelas atau di sekolah, (9) senang membantu teman dan orang lain, (10) aktif dalam kegiatan

sosial di sekolah dan di kelas serta aktif berorganisasi, (11) ingin selalu mengaktualisasikan berbagai ide cemerlangyang muncul dalam pikiran melalui kegiatan fantasi mereka. Aktualisasi ide tersebut dilakukan dengan cara berusaha mengajak teman sekolah dan orang lain untuk melakukan penelitian secara bersama di bawah komando siswa yang berbakat tersebut.

Kesemua karakteristik belajar, motivasi, kreativitas, dan kepemimpinan yang ditunjukkan oleh peserta didik yang berbakat tersebut, harus selalu menjadi perhatian bagi guru, orangtua, dan masyarakat dalam memberikan layanan pendidikan dan pembelajaran khusus kepada peserta didik yang berbakat, baik yang ada di sekolah-sekolah maupun yang ada di masyarakat. Melalui perhatian khusus dan bimbingan khusus kepada mereka yang tergolong peserta didik yang berbakat tersebut, maka bakat mereka yang menonjol tersebut akan dapat tumbuh dan berkembang secara maksimal dan optimal.

Jika bakat yang dimiliki oleh para peserta didik yang berbakat, baik yang ada di sekolah-sekolah maupun yang ada di masyarakat telah tumbuh dan berkembang, maka usaha pemberian layanan pendidikan dan pembelajaran khusus kepada mereka yang tergolong peserta didik yang berbakat harus dimaksimalkan dan dioptimalkan dengan memberikan perhatian dan bimbingan khusus kepada mereka yang tergolong peserta didik yang berbakat. Dengan tumbuh dan berkembangnya bakat peserta didik di sekolahsekolah secara maksimal dan optimal, maka para peserta didik yang berbakat tersebut, akan dapat menjadi tutor dan konselor sebaya bagi peserta didik lain, dan akan menjadi pelopor pembangunan di berbagai bidang kehidupan manusia, khususnya di Indonesia dan kepada semua ummat manusia di dunia ini.

Oleh karena itu, salah satu cara yang baik dan unggul untuk meningkatkan daya saing Indonesia di tengah-tengah persaingan 
global ialah melalui usaha pemberdayaan kepada sumberdaya manusia Indonesia yang berbakat, melalui pemberian layanan pendidikan dan pembelajaran khusus kepada peserta didik yang berbakat, agar menguasai IPTEKS tetapi berbudi pekerti yang luhur. Hanya dengan aktualisasi diri para peserta didik yang berbakat sebagai sumberdaya manusia yang unggul di Indonesia, kita dapat meningkatkan daya saing Bangsa Indonesia dalam persaingan penguasaan IPTEKS berskala dunia, seperti yang telah ditunjukkan oleh Profesor Habibie yang merebut ilmu Bangsa Jerman dalam menguasai Ilmu Aerodinamika, yaitu ilmu yang mengkaji tentang bagaimana cara membuat pesawat terbang.

\section{Meningkatkan Kekuatan Kompetitif Bangsa Indonesia di Era Globalisasi Melalui PembumianKarya Inovatif Fenomenal dan Spektakuler Peserta Didik Berbakat di Bidang MIPA}

Tidak dapat dipungkiri bahwa sejarah telah mencatat dan membuktikan bahwa negara-negara yang memiliki banyak sumberdaya manusia yang berbakat dan handal, memiliki daya saing yang tinggi jika dibandingkan dengan negara-negara yang kurang memiliki apalagi tidak memiliki sumberdaya manusia yang unggul. Sebagai contoh negara Jepang merupakan negara yang pernah hancur lebur sebagai akibat dari bom yang dijatuhkan di Hirosima dan di Nagasaki. Namun, Jepang kembali bangkit dengan memberikan perhatian khusus kepada

para guru yang masih hidup untuk kembali mendidik dan membelajarkan rakyat Jepang agar kembali memiliki literasi atau melek Ilmu Pengetahuan, Teknologi dan Seni (IPTEKS). Hal ini dilakukan oleh Kaisar Jepang dan pemerintah Jepang, yang pada akhirnya membuahkan hasil, yaitu Jepang kembali memiliki banyak sumberdaya manusia yang unggul, sehingga melalui aktualisasi bakat unggul yang dimiliki oleh sumberdaya manusia yang unggul tersebut, Jepang bangkit dan merebut teknologi serta menjadi negara maju yang menguasai teknologi otomotif, teknologi informasi, teknologi komunikasi, teknologi komputer, dan teknologi elektronika.

Sebaliknya, Indonesia dewasa tetap menjadi negara berkembang yang keadaannya tidak lebih baik daripada negara Malaysia dan Vietnam yang dulunya menjadi negara pengimpor tenaga kerja guru dari Indonesia yang dijadikan sebagai staf pengajar untuk mengajari rakyat Malaysia, sehingga Malaysia sekarang menjadi maju yang lebih mandiri dan kurang memiliki angka ketergantungan utang di Bank Dunia dan di Dana Moneter Internasional. Oleh karena itu, untuk meningkatkan daya saing bangsa Indonesia di Mancanegara yang berkelas dunia, maka usaha aktualisasi diri pada diri sumberdaya manusia yang berbakat dan sumberdaya manusia yang unggul sangat diperlukan.

Salah satu modal besar bagi kemajuan suatu negara, ialah jika dalam suatu negara tersebut memiliki jumlah sumberdaya manusia yang berbakat unggul dalam jumlah besar. Fakta telah menunjukkan kepada kita bahwa di negara maju seperti Jerman, Jepang, Amerika Serikat, Perancis, dan lainnya dapat menguasai berbagai bidang teknologi, karena memiliki sejumlah sumberdaya manusia yang berbakat unggul, yang mampu mengaktualisasikan dirinya melalui berbagai jenis pendidikan dan latihan dalam menguasai IPTEKS dalam berbagai bidang kehidupan manusia. Bahkan negara Singapura yang miskin sumberdaya alamnya dan tergolong negara kecil dilihat dari segi jumlah penduduk dan luas wilayahnya secara geografis, akan tetapi mampu menjadi negara maju yang menguasai IPTEKS dan menjadi macannya Asia karena aktualisasi diri dari para warga negaranya yang tergolong cerdas dan berbakat unggul dalam bidang IPTEKS.

Sebaliknya, Indonesia yang kaya akan sumberdaya alam terbesar di dunia dan memiliki jumlah penduduk yang besar, belum mampu meningkatkan statusnya dari negara berkembang menjadi negara maju yang menguasai IPTEKS, jika potensi-potensi unggul atau bakat-bakat unggul yang dimiliki oleh manusia Indonesia yang berbakat unggul, tidak dapat diaktualisasikan melalui proses pembelajaran, pendidikan, dan latihan di berbagai jenis dan jenjang pendidikan formal, informal, dan nonformal untuk manusia yang berbakat unggul tersebut. Agar para manusia Indonesia yang berbakat unggul dapat mengaktualisasikan potensinya secara optimal dan maksimal, maka fasilitas belajar untuk sumberdaya manusia yang unggul, harus tersedia dan lengkap di lingkungan pendidikan di rumah, di sekolah, dan di masyarakat, serta disain pembelajaran untuk SDM yang berbakat unggul tersebut harus dirancang sesuai dengan karakteristik, kecepatan belajar, dan kebutuhan belajar peserta didik yang berbakat unggul (Guilford, 1986).

Sumberdaya manusia yang berbakat unggul ialah mereka yang memiliki kemampuan intelektual yang unggul (Munandar, 1985). Dengan keunggulan ini, mereka diharapkan memiliki peluang besar untuk mencapai prestasi tinggi dan menonjol dalam bidang pekerjaannya. SDM yang 
berbakat unggul, juga dapat diartikan sebagai manusia yang memiliki kemampuan yang unggul di bidang intelektual, seni, dan olah raga, serta keterampilan tertentu (Kitano dan Kirby, 1986).

SDM yang memiliki kemampuan intelektual yang unggul sering dijuluki sebagai SDM yang jenius. SDM yang memiliki kemampuan atau bakat unggul pada satu keterampilan tertentu, misalnya berkemampuan luar biasa dalam bermain bola disebut sebagai SDM yang "Talented", dan SDM yang memiliki kemampuan atau bakat unggul pada beberapa keterampilan, misalnya berkemampuan luar biasa dalam bermain musik, akademik, dan olah raga di sekolah, maka SDM tersebut disebut sebagai SDM yang "Gifted".

Di era globalisasi pada abad ke-21 ini, negara yang sedang berkembang mengalami kompetisi yang luar biasa dalam berbagai bidang kehidupan (Toffler, 1988). Dalam upaya menjawab tantangan tersebut, maka pembangunan sumberdaya manusia melalui pendidikan harus menjadi prioritas utama bagi pihak keluarga, sekolah, masyarakat, dan pemerintah.

Salah satu komponen sumberdaya manusia yang sangat perlu diaktualisasikan potensinya sesuai dengan karakteristiknya yang unggul ialah sumberdaya manusia yang berbakat unggul. Agar potensi unggul yang dimiliki oleh para sumberdaya manusia yang unggul tersebut dapat teraktualisasikan

dengan baik, maka pemberian pendidikan khusus yang bermutu kepada mereka sangat diperlukan. Aktualisasi potensi yang dimiliki oleh sumberdaya manusia yang berbakat unggul sesuai dengan karakteristiknya yang unggul dapat terwujud melalui aktualisasi bakat unggul yang dimiliki dan pengembangan kreativitas yang dimiliki (Guilford, 1986). Selain itu, dukungan moril dan materil dari pihak keluarga, sekolah, dan masyarakat, serta pemerintah terhadap proses pendidikan bermutu untuk SDM yang berbakat unggul sangat menentukan, dan inovasi dalam perkembangan masyarakat demi untuk kepentingan masyarakat dan SDM yang berbakat unggul, juga diperlukan (Semiawan, 1993; Munandar, 1997; dan Joni, 1993).

Sejarah di negara lain membuktikan bahwa potensi-potensi keberbakatan, yang dimiliki oleh SDM yang berbakat unggul, dipelihara, ditumbuhkembangkan serta dipupuk melalui pendidikan khusus, pembelajaran khusus, serta layanan khusus agar mereka dapat menjadi pemimpin-pemimpin bangsa di hari esok, dan mengaktualisasikan dirinya dalam melakukan pembangunan di berbagai sektor kehidupan yang sarat dengan muatan pemuatan IPTEKS (Kitano dan Kirby, 1986). Para guru, orangtua, masyarakat, dan pemerintah tidak boleh membiarkan potensi-potensi unggul yang dimiliki oleh para SDM yang berbakat unggul dengan karakteristiknya yang unggul tidak teraktualisasikan, terutama dalam menghadapi berbagai perubahan yang disebabkan oleh berbagai revolusi di bidang IPTEKS. Kondisi seperti ini sangat menuntut aktualisasi potensi SDM yang berbakat unggul melalui pendidikan khusus, pembelajaran khusus, serta layanan khusus agar mereka dapat

memberikan sumbangan tenaga, pemikiran, dan jiwa raganya demi untuk kepentingan pembangunan masyarakat, bangsa, dan negara (Semiawan, 1995 dan Munandar, 1987). Oleh karena itu, para guru dan para orang dewasa memegang peranan yang sangat vital dalam membantu perkembangan aktual dan potensi peserta didik yang berbakat (Vygotski, 1978).

Mengabaikan pemberian pendidikan dan pembelajaran serta layanan khusus kepada SDM yang berbakat unggul, baik di lingkungan keluarga, sekolah, dan masyarakat, akan menyebabkan bakat intelektual, kreativitas, dan kemampuan unggul di bidang keterampilan tidak dapat teraktualisasikan, sehingga mereka tidak dapat memberikan kontribusi yang sangat besar terhadap pembangunan bangsa dalam berbagai bidang, dan pada akhirnya akan dapat menurunkan daya saing bangsa dalam percaturan negaranegara di dunia di era globalisasi dewasa ini.. Selain itu, pengabaian pemberian pendidikan khusus kepada SDM yang memiliki bakat yang unggul, juga akan dapat menyebabkan SDM yang berbakat unggul tersebut mengalami "underachiever", yaitu bakat anak berfungsi optimal dan maksimal sesuai dengan potensi unggul yang dimiliki (Barbe dan Renzulli, 1975; Gallagher, 1975). Oleh karena itu, pemberian pendidikan khusus kepada SDM yang berbakat unggul di Indonesia oleh semua pihak yang berkompeten, sangat diperlukan demi untuk meningkatkan daya bangsa Indonesia di percaturan dunia.

Terdapat sejumlah karakteristik yang unggul yang mencerminkan potensi unggul yang dimiliki oleh SDM yang berbakat unggul, yang perlu diaktualisasikan melalui pemberian layanan pendidikan dan pembelajaran khusus kepada mereka. Adapun karakteristik SDM yang berbakat unggul tersebut menurut Kitano dan Kirby (1986) yaitu memiliki perbendaharaan kata yang banyak, menaruh minat terhadap buku-buku pelajaran dan membacanya sejak usia dini, mampu membaca secara mandiri sejak usia 2 - 3 tahun, mampu 
mempersepsi hubungan kausal secara cepat dan tepat, dorongan ingin tahunya sangat besar (curiousity), belajar dengan cepat dan dapat mengungkap kembali berbagai informasi dengan cepat dan tepat, bekerja keras untuk aktualisasi diri, senang bergaul dengan orang dewasa, mampu berkonsentrasi dalam waktu yang lama, memiliki standar diri yang tinggi, menyukai pengalaman baru yang menantang, awet dan setia dalam menyimpan berbagai informasi, cakap dalam menyusun rencana, cepat dalam memecahkan masalah, dan mampu berpikir abstrak.

Selain itu, karakteristik lain yang khas dari SDM yang berbakat unggul adalah: siswa yang berbakat cepat mengambil generalisasi dan melihat pebedaan dan persamaan sesuatu, mudah bosan terhadap tugas-tugas yang rutin dan monoton, menaruh perhatian yang mendalam terhadap isu-isu etika, agama, dan politik, serta perbendaharaan informasinya sangat banyak dan bervariasi.

Marland (1986) mengemukakan bahwa ciri khas keunggulan dari peserta didik yang berbakat unggul yaitu meliputi: berinteligensi tinggi, memiliki kecakapan akademik khusus, berpikir kreatif dan produktif, cakap dalam memimpin, cakap dalam bidang seni visual, dan memiliki kecakapan

psikomotorik. Dengan karakteristik yang dimiliki oleh SDM yang berbakat unggul tersebut, maka jika para SDM yang berbakat unggul tersebut diberikan layanan pendidikan dan latihan khusus untuk mereka sesuai dengan keunggulan-keunggulan yang dimiliki dan diajar oleh guru yang unggul serta ditunjang oleh fasilitas belajar yang memadai, maka SDM yang berbakat unggul tersebut akan dapat mengaktualisasikan potensinya secara maksimal danoptimal, serta dapat memberikan andil yang sangat besar dalam meningkatkan daya saing Bangsa Indonesia untuk mengarungi saratnya kompetisi global dalam

berbagai aspek kehidupan dan penghidupan manusia dalam era informasi dengan globalisasinya yang menonjol dewasa ini.

Berbagai fakta menunjukkan kepada kita tentang kontribusi SDM yang berbakat unggul dalam meningkatkan daya saing Bangsa Indonesia di percaturan dunia, yaitu sebagai contohnya Professor Habibie sebagai SDM berbakat unggul di bidang intelektual dan di bidang teknik aerodinamika, telah meningkatkan daya saing Bangsa Indonesia dalam rancang bangun pesawat terbang yang berskala dan berkelas dunia. Bahkan ekor dari salah satu pesawat tempur Amerika Serikat adalah buah tangan dari Professor Habibie yang telah mendapatkan hak patent dari
Amerika Serikat. Selain itu, Professor Habibie juga telah mengangkat daya saing Bangsa Indonesia di bidang pembuatan kapal laut dalam skala kecil, sedang, dan besar melalui PT. PAL Surabaya. Keberhasilan perusahaan ini dalam memproduksi kapal laut adalah tidak terlepas dari rintisan dan bimbingan Professor Habibie. Dengan kata lain, sejak beliau menjabat sebagai Menristek RI selama pemerintahan Orba Baru

menjadi Presiden Republik Indonesia yang ketiga, daya saing Bangsa Indonesia di bidang riset dan teknologi meningkat secara signifikan.

Di bidang pembangunan hukum, salah satu SDM unggul yang merupakan putera Bangsa Indonesia yang telah mengangkat daya saing Bangsa Indonesia di bidang perumusan dan pemberlakuan hukum nasional dan internasional melalui kebijakan luar negerinya, yang diterapkan saat berkali-kali menjabat sebagai Menteri Luar Negeri Republik Indonesia ialah Professor Mochtar Kusumaatmaja. Selama beliau ini menjabat sebagai Menteri Luar Negeri Republik Indonesia berkali-kali, Indonesia menjadi juru runding bagi penyelesaian masalah Timur Tengah dan menjadi Tim Penyusun dan Perumus Hukum Internasional atas mandat yang dipercayakan Perserikatan Bangsa-Bangsa kepada Indonesia.

Dari dua contoh SDM yang berbakat unggul dimiliki oleh Indonesia yang tersebut di atas, yang telah mengangkat derajat dan daya saing Bangsa Indonesia di dunia internasional, menunjukkan kepada kita bahwa SDM Indonesia yang berbakat unggul, sangat memiliki kontribusi yang sangat besar

dalam meningkatkan daya saing Bangsa Indonesia, baik di masa lalu, di masa kini, dan di masa yang akan datang. Oleh karena itu, sangat diharapkan kepada semua komponen bangsa dan kepada senua pihak terkait untuk selalu memberikan perhatian khusus kepada mereka dan memfasilitasi berbagai kebutuhan yang diperlukan oleh para SDM yang berbakat unggul tersebut, agar mereka dapat mengaktualisasikan berbagai potensi yang dimiliki melalui proses

pendidikan dan latihan yang bersifat khusus sesuai minat, perhatian, kebutuhan, dan potensi yang dimiliki.

Sumberdaya manusia yang berbakat unggul memiliki sejuta potensi-potensi unggul yang perlu diaktualisasikan melalui pemberian pendidikan dan pembelajaran khusus sesuai dengan kemampuan unggul yang dimiliki. Potensi-potensi unggul yang dimiliki oleh SDM yang berbakat unggul, misalnya potensi aktualisasi diri di bidang Ilmu Pengetahuan, Teknologi, dan Seni (IPTEKS), olah raga, 
seni, dan berbagai keterampilan lainnya. Potensi-potensi unggul tersebut perlu ditumbuhkembangkan oleh pihak keluarga, sekolah, dan masyarakat, serta pemerintah melalui berbagai jenis dan bentuk program pendidikan dan latihan yang bersifat khusus sesuai dengan minat dan kebutuhan SDM yang berbakat unggul tersebut. Dengan aktualisasi potensi yang dimiliki oleh para SDM yang berbakat unggul tersebut, maka diharapkan daya saing Bangsa Indonesia di mata dunia internasional juga dapat ditingkatkan.

\section{Referensi}

Guidford, J.P. 1986. Creative Talents: Their Nature Uses and Development.Buffalo New York: Bearly Limited.

Kitano, M.K. dan Kirby, D.F. 1989. Gifted Education: A Comprehensive View. Boston: Little, Brown, and Company.

Mangunhardjana, A.M. 1986. Mengembangkan Kreativitas. Yogyakarta: Kanisius.

Marland, 1986. Education for Gifted.

Munandar, S.C.U. 1985. Bunga Rampai Anak-anak Berbakat: Pembinaan dan Pendidikannya. Jakarta: Rajawali.

Semiawan, C. 1995. Perspektif Pendidikan Anak Berbakat. Jakarta: Depdikbud.

---, dkk., 1987. Memupuk Bakat dan Kreativitas Siswa Sekolah Menengah: Petunjuk bagi Guru dan Orangtua. Jakarta: Gramedia. 